\title{
UJI SENSORI DAN PENENTUAN INDEKS GLIKEMIK NASI BERAS PUTIH (Oryza satifa L.) SUBTITUSI PISANG KEPOK (Musa paradisiaca forma typical) SEBAGAI MAKANAN POKOK ALTERNATIF PENDERITA DIABETES MELLITUS TIPE 2
}

\author{
[Sensory Test and Determination of The Glycemic Index of White Rice (Oryza sativa I.) with Substitution of Kepok Banana \\ (Musa paradisiaca forma typical L) as Alternative Staple Food for Type 2 Diabetes Mellitus Patients]
}

Febriana Muchtar ${ }^{*}$, Paridah $^{1}$, Irma Yunawati ${ }^{1}$

1Prodi Gizi, Fakultas Kesehatan Masyarakat, Universitas Halu Oleo

*Email: febrianamuchtar9@uho.ac.id(Tlp:+628114000874)

Diterima tanggal 15 November 2021

Disetujui tanggal 24 November 2021

\begin{abstract}
This study aimed to obtain the proportion of white rice and kepok banana based on sensory test results and the glycemic index of white rice with a substitution of kepok bananas. The research design used was an experimental method with a non-factorial Completely Randomized Design (CRD). The variation was in the proportion of white rice and kepok banana namely 60\% : 40\% (NP1), 50\% : 50\% (NP2) dan 40\% : 60\% (NP3). Each treatment was repeated three times. The sensory test was carried out using the hedonic test (level of preferences). The glycemic index was analyzed through the area under the curve (AUC) ratio of glucose response of food by measuring blood glucose levels during fasting for 30, 60, 90, and 120 minutes after consuming test foods (white rice with a substitution of kepok banana) and control (bread). The collected data were then analyzed using ANOVA and was followed by DMRT if there was a significant difference between treatments. The result of the research shows that in the sensory test, the proportion of white rice and kepok banana had no significant effect on color and aroma, but had a significant effect on texture and very significant effect on the taste of white rice with a substitution of kepok banana. The best treatment was obtained in the proportion of white rice and kepok banana 60\%: 40\% (NP1), with preference scores of color, aroma, texture, and taste reached 3.08 (like), 2.68 (like), 3.16 (like) and 3.12 (like), respectively. The selected treatment had a 20.13\% glycemic index (low).
\end{abstract}

Keywords: Sensory test, glycemic index, white rice, kepok banana,diabetes mellitus

\begin{abstract}
ABSTRAK
Tujuan penelitian untuk mendapatkan perbandingan nasi beras putih dan pisang kepok yang terbaik berdasarkan hasil uji sensori dan indeks glikemik nasi beras puth yang disubtitusi pisang kepok. Penelitian menggunakan metode eksperimen dengan Rancangan Acak Lengkap (RAL). Perlakuan terdiri atas 3 variasi perlakuan yaitu perbandingan nasi beras putih : pisang kepok 60\%: 40\% (NP1), 50\%: 50\% (NP2) dan 40\%:60\% (NP3). Masing-masing perlakuan dibuat 3 kali ulangan. Uji sensori menggunakan uji hedonik (tingkat kesukaan) dan penentuan indeks glikemik dengan perhitungan perbandingan luas di bawah kurva (area under curve). Respon glukosa makanan melalui hasil pengukuran glukosa darah saat puasa; 30; 60; 90 dan 120 menit setelah konsumsi makanan uji yaitu nasi putih subtitusi pisang kepok dan makanan kontrol yaitu roti. Data hasil uji sensori dianalisis dengan metode Analisis of Varians (ANOVA) dan perlakuan yang berpengaruh nyata dilakukan uji lanjut dengan analisis DMRT. Berdasarkan hasil analisis uji sensori perbandingan nasi beras putih dan pisang kepok tidak berpengaruh nyata terhadap warna dan aroma, tetapi berpengaruh nyata terhadap tekstur dan berpengaruh sangat nyata terhadap rasa nasi beras putih subtitusi pisang kepok. Perlakuan terbaik diperoleh pada perlakuan nasi beras putih : pisang kepok 60\% : 40\% (NP1), dengan tingkat kesukaan terhadap warna 3,08 (suka), aroma 2,68 (suka), tekstur 3,16 (suka) dan rasa 3,12 (suka) serta nilai indeks glikemik 20,13\% dengan kategori indeks glikemik rendah.
\end{abstract}

Kata kunci: Uji sensori, indeks glikemik, nasi beras putih, pisang kepok, diabetes melitus 


\section{PENDAHULUAN}

Salah satu penyakit endokrin yang paling sering ditemukan adalah diabetes melitus (Momongan et al., 2019). Diabetes melitus termasuk penyakit kronis yang disebabkan oleh rendahnya produksi insulin yang berfungsi untuk mengatur glukosa darah (Bestari, 2020). Hormon insulin yang dilepaskan harus memenuhi kebutuhan metabolisme. Oleh sebab itu pengaturan pembentukan dan pelepasan insulin serta respon insulin sebaiknya berjalan dengan normal. Hal ini dapat menyebabkan terjadinya ketidakseimbangan metabolisme dan merupakan patogenesis terjadinya diabetes melitus tipe 2 (Garcia et al., 2020). Diabetes dapat mempengaruhi kemampuan dan kualitas hidup seseorang, serta menyebabkan morbiditas dan kematian dini (Khan et al., 2020).

Federasi Diabetes Interantional (IDF) memprediksi bahwa pada tahun 2017 terdapat sekitar 451 juta orang dewasa di seluruh dunia menderita diabetes, dan jumlah tersebut akan meningkat menjadi 693 juta pada tahun 2045 jika tidak dilakukan upaya pencegahan yang efektif (Lin et al., 2020). Riset kesehatan Dasar tahun 2018 menunjukkan peningkatan prevalensi penderita diabetes melitus di Indoensia berdasarkan hasil diagnosis dokter pada umur 15 tahun yaitu sebesar 1,5\% pada tahun 2013 menjadi $2 \%$. Demikian pula prevalensi diabetes melitus berdasarkan pemeriksaan gula darah, mengalami peningkatan dari 6,9\% pada tahun 2013 menjadi 8,5\% pada tahun 2018 (Pangribowo, 2020).

Faktor genetik dan gaya hidup, khususnya makanan merupakan faktor yang mempengaruhi terjadinya diabetes melitus tipe 2 (Toi et al., 2020). Hasil penelitian menunjukkan bahwa mengonsumsi makanan dengan indeks glikemik rendah dapat menurunkan risiko diabetes melitus tipe 2, risiko resisten insulin dan sindrom metabolik menjadi lebih rendah (Henry et al., 2021). Pengaturan makanan merupakan salah satu upaya penanganan diabetes melitus, yaitu dengan memberikan jenis makanan dengan nilai indeks glikemik rendah (Puspaningtyas et al., 2020). Kebutuhan zat gizi penderita diabetes melitus harus tetap terpenuhi dengan mengonsumsi makanan yang cukup (Zaddana et al., 2021).

Beras dikonsumsi sebagai nasi putih yang dihasilkan dari proses penggilingan yang dapat menyebabkan rendahnya serat, polifenol dan zat gizi mikro misalnya magnesium yang dapat bermanfaat dalam proses metabolisme glukosa. Nasi putih memiliki indeks glikemik tinggi yang dapat meningkatkan kadar glukosa darah (Van Dam, 2020). Penderita diabetes melitus tidak diperbolehkan mengonsumsi nasi yang berbahan baku beras dalam jumlah banyak (Riandani, 2013). Keanekaragaman hayati yang dimiliki Indonesia merupakan sumber pangan karbohidrat yang dapat dimanfaatkan untuk menyediakan bahan pangan pokok selain beras, khususnya bagi penderita diabetes mellitus (Diyah et al., 2016).

Pisang merupakan salah satu sumber karbohidrat kompleks dan simpel yang dapat dimanfaatkan sebagai sumber energi. Pisang mengandung bebebrapa komponen aktif seperti serat, flavonoid dan magnesium yang memberikan efek hipoglikemik yaitu penurunan kadar glukosa darah dan kolesterol. Efek ini nampak setelah 
mengonsumsi satu hingga dua buah pisang kurang lebih 250 gram sehari. Jenis pisang kepok dengan kandungan serat seperti pati resisten dan inulin memberikan pengaruh terhadap kadar glukosa darah. Kandungan flavonoid pisang kepok dapat memberikan efek peningkatan sensitifitas insulin (Wahyuni \& Syauqy, 2015). Buah pisang dapat dimanfaatkan sebagai alternatif obat tradisional untuk menurunkan kadar glukosa darah. Pisang kepok mentah (unripe) banyak mengandung tanin, dimana tanin memberikan pengaruh terhada penurunan glukosa darah, selain flavonoid, triterpenoid dan steroid sehingga dapat dimanfaatkan untuk pengobatan tardisional penyakit diabetes mellitus (Bawati \& Linawati, 2013).

Masyarakat Wajo, Sulawesi Selatan telah lama mengonsumsi campuran nasi puth dan pisang kepok mentah. Jenis makanan ini disebut dalam bahasa Bugis nanre pule otti. Campuran nasi puth dan pisang kepok mentah diduga dapat menurunkan nilai indeks glikemik nasi puth sehingga aman dikonsumsi oleh penderita diabetes melitus. Penelitian ini bertujuan untuk mendapatkan formula proporsi nasi putih dan pisang kepok mentah yang disukai berdasarkan hasil uji sensori serta menentukan nilai indeks glikemiknya.

\section{BAHAN DAN METODE}

\section{Bahan}

Bahan-bahan yang digunakan terdiri dari bahan utama berupa beras putih jenis beras kepala,merk Pokea yang dibeli dari pasar tradisional kota Kendari, pisang kepok mentah diperoleh dari pengusaha keripik pisang di kota Kendari. Bahan pendukung terdiri atas air mineral dan roti tawar yang digunakan sebagai makanan standar untuk penentuan nilai indeks glikemik. Bahan kimia yang digunakan untuk analisis adalah aquades, n-heksana (teknis), $\mathrm{NaOH}$ (teknis), $\mathrm{HCl}$ (teknis), $\mathrm{H}_{2} \mathrm{SO}_{4}$ (teknis), $\mathrm{H}_{3} \mathrm{BO}_{3}$ (teknis), $\mathrm{CuSO}_{4}$ (teknis), alkohol (Merck), metanol (teknis) dan DPPH (1,1-difenil-2- pikrilhidrazil) (Sigma).

\section{Tahapan Penelitian}

\section{Pembuatan Nasi beras putih dan pisang kepok}

Pembuatan nasi beras puth subtitusi pisang kepok dilakukan dengan metode pengukusan yang sebelumnya beras puth diaron terlebih dulu. Metode pengukusan beras puth berdasarkan penelitian yang dilakukan oleh (Indah \& Putri, 2020). Beras dicuci hinga bersih menggunakan air bersih, kemudian beras dimasak hingga setengah matang (aron). Selanjutnya proses pemasakan beras (tahap aron) dilakukan dengan api kecil dan tidak terlalu panas (Giyatmi \& Anggraini, 2017). Proses pemasakan menggunakan panci yang ditambahkan air sebanyak satu ruas jari yang diukur dari permukaan beras. Setelah air beras habis,panci diangkat. Siapkan panci kukusan dan panaskan beberapa saat hingga mendidih, masukan beras yang telah diaron, bersamaan dengan pengukusan beras ditambahkan potongan pisang kepok yang sebelumnya telah disiapkan dengan bentuk dadu. Proses pengukusan kurang lebih 35 menit. Setelah matang, angkat dan dinginkan. Selanjutnya 
setelah nasi beras putih subtitusi pisang kepok dingin, masukan ke dalam wadah plastik yang telah diberi label untuk pengujian sensori.

\section{Penilaian Sensori (Rampengan et al., 1985; Nabil et al., 2020)}

Sifat sensori sampel nasi beras putih subtitusi pisang kepok dianalisis melalui uji sensori dengan uji hedonik oleh 25 panelis tidak terlatih. Panelis adalah mahasiswa yang menjadi panelis uji sensori terhadap warna, aroma, tekstur dan rasa produk. Uji sensori dilakukan dengan menggunakan skala hedonik 1 sampai 4 (4: sangat suka, 3: suka, 2: agak suka dan 1: tidak suka). Sampel disajikan pada suhu kamar dengan menggunakan wadah plastik bening berlale tiga angka acak. Sampel disajikan secara acak dan pengujian dilakukan sesaat setelah proses pembuatan nasi beras puth subtitusi pisang kepok. Uji sensori dilakukan dalam ruangan pada suhu kamar disertai kondisi penerangan yang baik. Panelis diinstruksikan minum air putih di antara mencicipi setiap sampel untuk meminimalkan rasa yang tersisa dari sampel sebelumnya. Hasil analisis sensori yang paling disukai akan dilakukan analisis proksimat dan penentuan indeks glikemik.

\section{Analisis Proksimat}

Analisis proksimat meliputi analisis karbohidrat dengan metode Luff Scrhoorl (AOAC, 2005), kadar serat kasar menggunakan metode refluks (AOAC, 2005), kadar protein menggunakan metode kjedahl (AOAC, 2005), dan kadar lemak dengan metode ekstraksi soxhlet (AOAC, 2005).

\section{Penentuan Indeks Glikemik (Ningrum et al., 2013)}

Penentuan nilai indeks glikemik dilakukan dengan pemeriksaan glukosa darah pada subjek, yakni relawan berjumlah 8 orang yang telah bersedia dengan menandatangani infomed consent. Penelitian ini telah memperoleh kelaikan Etik (Ethical Clearance) surat dengan Nomor: 1602a/UN29.20.1.2/PG/2021.

Nasi Beras Puth subtitusi pisang kepok yang akan ditentukan indeks glikemiknya (mengandung $50 \mathrm{~g}$ karbohidrat) diberikan kepada relawan yang telah menjalani puasa penuh (kecuali air) selama semalam (sekitar pukul 20.00 sampai pukul 08.00 pagi besoknya). Selama dua jam pasca pemberian, sampel darah sebanyak 50 $\mu \mathrm{L}$ - finger-prick capillary blood samples method- diambil setiap 15 menit pada jam pertama kemudian setiap 30 menit, 60 menit, 90 menit dan 120 menit untuk diukur kadar glukosanya. Pada waktu berlainan hal yang sama dilakukan dengan memberikan $50 \mathrm{~g}$ roti tawar kepada relawan. Indeks glikemik ditentukan dengan membandingkan luas daerah di bawah kurva antara pangan yang diukur indeks glikemik-nya dengan pangan acuan. Menghitung luas area di bawah kurva dengan rumus:

$$
\mathrm{L}=\frac{\Delta 30 t}{2}+\Delta 30 t+\frac{\Delta 60 t-\Delta 30 t}{2}+\Delta 60 t+\frac{\Delta 90 t-\Delta 60 t}{2}+\Delta 90 t+\frac{\Delta 1200 t-\Delta 90 t}{2}
$$

Keterangan: $\mathrm{L}=$ luas area dibawah kurva; $\mathrm{t}=$ Interval waktu pengambilan darah (30 menit); $\Delta 30=$ selisih kadar glukosa darah 30 menit setelah beban dengan puasa; $\Delta 60=$ selisih kadar glukosa darah 60 menit setelah beban dengan puasa; $\Delta 90$ = selisih kadar glukosa darah 90 menit setelah beban dengan puasa; $\Delta 120=$ selisih kadar glukosa darah 120 menit setelah beban dengan puasa. 
Menghitung indeks glikemik dengan cara menghitung luas area di bawah kurva respon glukosa darah setelah mengonsumsi nasi beras putih subtitusi pisang kepok, dengan rumus sebagai berikut:

$$
\text { indeks glikemik }=\frac{\text { luas area di bawsah kurva makanan uji }}{\text { luas area di bawwah kurva makanan standar }} \times 100
$$

\section{Penentuan Glukosa Darah}

Data glukosa darah relawan diperoleh melalui pemeriksaan glukosa darah menggunakan gluko meter Nesco. Responden dipilih berdasarkan kriteria penelitian yaitu memiliki status gizi normal yang ditentukan dengan mengukur IMT dan lingkar pinggang responden, memiliki kadar glukosa darah puasa normal, tidak memiliki riwayat penyakit diabetes dan tidak alergi dengan makanan yang akan diberikan.

Data Karakteristik relawan diperoleh dengan melakukan pengisian kuesioner (biodata, riwayat penyakit, riyawat merokok). Data Indeks Massa Tubuh dan linggar pinggang (relawan harus mempunyai IMT normal) dilakukan dengan pengukuran antropometri relawan yang terdiri pengukuran berat badan dan tinggi badan.

\section{Rancangan Penelitian}

Penelitian ini menggunakan Rancangan Acak Lengkap (RAL) non faktorial dengan 3 ulangan, sehingga diperoleh9 unit percobaan. Perlakuan dalam penelitian ini adalah nasi beras putih subtitusi pisang kepok dengan perbandingan sebanyak 3 taraf yaitu NP1 (nasi beras putih 60\% : pisang kepok 40\%), NP2 (nasi beras putih $50 \%$ : pisang kepok $50 \%$ ), dan NP3 (nasi beras putih 40\% : pisang kepok 60\%).

\section{Analisis Data}

Data hasil uji sensori dianalisis dengan menggunakan sidik ragam (Analysis of Varian), hasil pengujian yang berpengaruh nyata terhadap variabel penelitian, dilanjutkan dengan uji lanjut Duncan's Multiple Range Test (DMRT) pada taraf kepercayaan $95 \%(a=0,05)$.

\section{HASIL DAN PEMBAHASAN}

\section{Uji Sensori}

Hasil rekapitulasi analisis ragam pengaruh subtitusi pisang kepok pada nasi beras putih terhadap parameter sensori yang terdiri dari warna, aroma, tekstur dan rasa disajikan pada Tabel 1.

Tabel 1. Rekapitulasi analisis ragam pengaruh nasi beras putih substitusi pisang kepok terhadap karakteristik Sensori nasi beras putih subtitusi pisang kepok

\begin{tabular}{ccc}
\hline No & Variabel Pengamatan & Analisis Ragam \\
\hline 1 & Warna & tn \\
2 & Aroma & tn \\
3 & Tekstur & $*$ \\
4 & Rasa & ${ }^{* *}$ \\
\hline
\end{tabular}

Keterangan: ${ }^{* *}=$ berpengaruh sangat nyata, ${ }^{*}=$ berpengaruh nyata, $\mathrm{tn}=$ berpengaruh tidak nyata 
Berdasarkan hasil analisis sidik ragam yang tersaji pada Tabel 2, nasi beras putih subtitusi pisang kepok tidak berpengaruh terhadap warna dan aroma tetapi berpengaruh nyata terhadap tekstur dan berpengaruh sangat nyata terhadap rasa nasi beras putih subtitusi pisang kepok. Hal ini menunjukkan bahwa perlakuan perbandingan nasi beras putih dan pisang kepok tidak mempengaruhi warna dan aroma tetapi mempengaruhi tekstur dan rasa. Menurut (Adi et al., 2020) bahwa suhu pemasakan akan mempengaruhi kualitas fisik dan warna beras. Berdasarkan hasil analisis sidik ragam, perlakuan subtitusi pisang kepok berpengaruh terhadap tekstur dan rasa. Proses pemasakan nasi bertujuan untuk mencapai proses gelatinisasi pati yang sempurna dan menhasilkan tekstur yang diinginkan (Chapagai et al., 2017). Rasa nasi dapat dipengaruhi oleh metode pemasakan. Metode pemasakan konvensional dengan cara pengukusan menyebabkan nasi terasa lebih manis (Adi et al., 2020).

Rata-rata hasil penilaian panelis terhadap sifat sensori yang meliputi warna, aroma, tekstur dan rasa nasi beras putih subtitusi pisang kepok disajikan pada Tabel 2 .

Tabel 2. Hasil uji sensori terhadap warna, aroma, tekstur dan rasa nasi beras putih subtitusi pisang kepok

\begin{tabular}{ccccc}
\hline Perlakuan & \multicolumn{1}{c}{ Warna } & \multicolumn{1}{c}{ Aroma } & \multicolumn{1}{c}{ Tekstur } & \multicolumn{1}{c}{ Rasa } \\
\hline NP1 (Nasi beras puth 60\% : pisang kepok 40 \%) & $3,08^{\mathrm{a}} \pm 0,70$ & $2,68^{\mathrm{a}} \pm 0,85$ & $3,16^{\mathrm{a}} \pm 0,8$ & $3,12^{\mathrm{a}} \pm 0,78$ \\
NP2 (Nasi beras puth 50\% : pisang kepok 50\%) & $2,96^{\mathrm{a}} \pm 0,79$ & $2,6^{\mathrm{a}} \pm 0,24$ & $2,64^{\mathrm{b}} \pm 0,74$ & $2,6^{\mathrm{b}} \pm 0,78$ \\
NP3 (Nasi beras puth 40\% : pisang kepok 60\%) & $2,96^{\mathrm{a}} \pm 0,67$ & $2,84^{\mathrm{a}} \pm 0,75$ & $2,72^{\mathrm{b}} \pm 0,91$ & $2,76^{\mathrm{ab}} \pm 0,58$
\end{tabular}

Keterangan : Angka-angka yang diikuti oleh huruf yang berbeda pada kolom yang sama berbeda sangat nyata pada taraf kepercayaan $95 \%$.

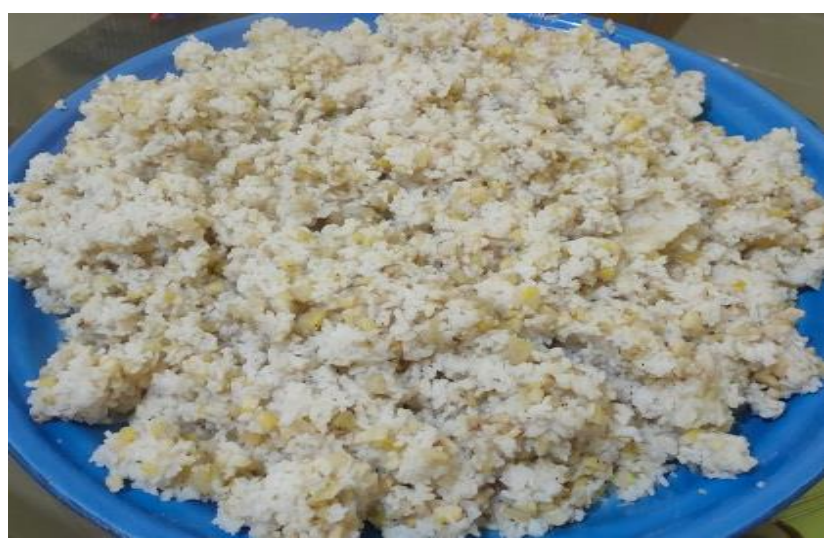

Gambar 1. NP1 (nasi beras putih : pisang kepok 60\%:40\%) perlakuan terpilih berdasarkan hasil uji sensori

\section{Warna} terhadap nasi beras putih subtitusi pisang kepok

Berdasarkan hasil analisis uji sensori yang disajikan Tabel 2, diperoleh tingkat kesukaan warna panelis terhadap warna nasi beras putih subtitusi pisang kepok adalah 2,96 hingga 3,08 dengan nilai rata-rata berkategori suka. Penilaian panelis terendah 2,96 pada perlakuan NP2 dan NP3 (suka) sedangkan penilaian panelis tertinggi 3,08 (suka) pada perlakuan NP1. Warna yang terbentuk disebabkan oleh bahan-bahan yang digunakan,dimana pada perlakuan ini proporsi penggunaan nasi beras putih pada perlakuan NP1 lebih banyak 
sehingga menghasilkan warna putih yang lebih jelas. Warna merupakan sifat sensori yang paling pertama dapat dilihat secara langsung oleh konsumen. Mutu bahan makanan sangat dipengaruhi oleh warna yang dimiliki, warna yang terbentuk dan tidak mengalami perubahan yang menyimpang dapat mempengaruhi penilaian panelis (Negara et al., 2016). Aspek visual sangat berperan penting dalam pemilihan produk makanan. Salah satu konstituen utama dari makanan dan minuman adalah warnanya (Dilrukshi et al., 2019).

\section{Aroma}

Hasil uji sensori terhadap aroma nasi beras putih subtitusi pisang kepok pada Tabel 2 diperoleh bahwa semua perlakuan disukai oleh panelis. Nilai rata-rata hasil penilaian panelis terhadap aroma nasi beras puth subtitusi pisang kepok adalah 2,6 (suka) hingga 2,84 (suka). Penilaian panelis terendah 2,6 dengan kategori suka diperoleh pada perlakuan NP2 (Nasi beras putih 50\% : pisang kepok $50 \%$ ) dan rata-rata penilaian tertinggi pada perlakuan NP3 (Nasi beras putih 40\% : pisang kepok $60 \%$ ) dengan nilai 2,84 berkategori suka. Nampak bahwa panelis menyukai perlakuan dengan proporsi pisang kepok yang lebih banyak. Aroma pada makanan disebabkan oleh asam-asam organik berupa ester dan volatil. Aroma makanan akan terbentuk selama proses pemasakan seperti dipanggang, direbus dan digoreng (Julfan et al., 2016). Aroma makanan terbentuk karena kandungan senyawa yang sifatnya mudah menguap dan merupakan hasil reaksi yang disebabkan oleh aktivitas enzim maupun tanpa adanya aktivitas enzim. Aroma dapat digunakan sebagai indikator kerusakan makanan. Aroma yang menyimpang menandakan bahwa makanan telah mengalami kerusakan (Muchtar et al., 2020).

\section{Tekstur}

Berdasar Tabel 2, rata-rata hasil pengujian sensori terhadap tektur nasi beras putih subtitusi pisang kepok diperoleh tingkat kesukaan panelis tertinggi 3,16 (suka) pada perlakuan NP1 (Nasi beras putih 60\%: pisang kepok $40 \%$ ) dan terendah 2,64 (suka) pada perlakuan NP2 (Nasi beras putih 50\% : pisang kepok $50 \%$ ). Perlakuan NP1 lebih disukai karena proporsi nasi yang lebih banyak dibandingkn pisang kepok.Proporsi nasi beras putih lebih banyak menyebabkan tekstur lebih pulen yang disebabkan oleh jenis beras yang digunakan yaitu beras kepala. Kandungan nasi berupa amilosa dan sebagian amilopektin mempengaruhi tesktur produk pangan yang dihasilkan. Perbandingan antara kadar amilosa dan amilopektin beras merupakan faktor yang dapat mempengaruhi mutu nasi yang dihasilkan, yaitu warna dan tekstur nasi, baik pada keadaan nasi hangat maupun nasi telah dingin (Sari et al., 2020). Amilosa dapat mempengaruhi mutu tanak, tingkat kepulenan atau tekstur nasi yang dihasilkan (Syamsiah \& Masliah, 2019).

\section{Rasa}

Tabel 2 menunjukan bahwa rata-rata hasil pengujian sensori terhadap rasa nasi beras putih subtitusi pisang kepok diperoleh tingkat kesukaan panelis tertinggi 3,12 (suka) pada perlakuan NP1 (Nasi beras putih 60\% : pisang kepok $40 \%$ ) dan terendah 2,6 (suka) pada perlakuan NP2 (Nasi beras putih 50\% : pisang kepok $50 \%$ ). Perlakuan NP1 lebih disukai karena jumlah proporsi nasi lebih banyak dibandingkn jumlah pisang kepok. Proporsi 
nasi beras putih lebih banyak mempengaruhi cita rasa nasi beras puth subtitusi pisang kepok. Beras kepala mengandung amilosa lebih rendah dibandingkan amilopektin, sehingga mempengaruhi rasa nasi yang dihasilkan. Kadar amilosa mempengaruhi kualitas rasa,kepulenan dan sifat fisik yang lain. Beras yang mengandung lebih banyak amilosa memiliki sifat nasi yang keras atau pera, sebaliknya beras yang mengandung kadar amilosa rendah menghasilkan nasi yang pulen (Syamsiah \& Masliah, 2019). Tingkat penerimaan nasi dipengaruhi oleh beberapa faktor yaitu tingkat keputihan, aroma dan kepulenan. Hal ini menunjukan bahwa mutu suatu makanan ditentukan oleh cita rasa, warna, tekstur,kandungan gizi dan mutu mikrobiologi (Setyowati \& Kurniawati, 2015).

\section{Nilai Proksimat Nasi Beras Putih Subtitusi Pisang Kepok}

Rekapitulasi hasil analisis nilai proksimat nasi beras putih subtitusi pisang kepok terpilih adalah pada perlakuan NP1 (nasi beras puth : pisang kepok 60\%: 40\%). Hasil analisis proksimat yang terdiri atas kadar lemak, kadar protein, kadar karbohidrat dan kadar serat kasar disajikan pada Tabel 3.

Tabel 3. Nilai proksimat nasi beras putih subtitusi pisang kepok

\begin{tabular}{clc}
\hline No & Nilai Proksimat (\%) & NP1 (\%) \\
\hline 1 & Lemak & 0,037 \\
2 & Protein & 2,719 \\
3 & Karbohidrat & 56,25 \\
4 & Serat kasar & 12,425
\end{tabular}

\section{Kadar Lemak}

Berdasarkan hasil analisis proksimat, diperoleh bawah kandungan lemak nasi beras puth subtitusi pisang kepok pada perlakuan NP1 (nasi beras putih : pisang kepok 60\% : 40\%) adalah 0,037\%. Kedua bahan yang digunakan merupakan bahan baku yang tidak memberikan kadar lemak yang tinggi karena baik nasi putih maupun pisang kepok bukan merupakan bahan pangan sumber lemak. Kandungan utama pada nasi dan pisang kepok mentah adalah karbohidrat.

Lemak sebagai zat gizi yang memiliki peran penting untuk kesehatan manusia terdapat hampir di semua bahan pangan dengan kandungan yang berbeda-beda (Sundari et al., 2015). Nasi tidak mengandung lemak, kolesterol dan juga bebas sodium (Chaudhari et al., 2018). Beras adalah golongan serealia yang sangat digemari sebagai makanan pokok di berbagai wilayah di dunia, khususnya di negara-negara tropis. Beras merupakan sumber karbohidrat kompleks dan sebagai salah satu sumber energi. Untuk penduduk di wilayah Asia, beras serta produk turunannya memberikan kontribusi energi sebesar 60-70\% (Fairulnizal et al., 2015). Pisang merupakan makanan penting di beberapa negara berkembang, termasuk Indonesia (Nurhayati \& Rahmanto, 2016). Konsumsi pisang mentah semakin meningkat karena potensi zat gizi dan manfaat fisiologis bagi kesehatan manusia (Falcomer et al., 2019). Terdapat beberapa kandungan zat gizi yang penting untuk tubuh yaitu pati, serat pangan, pati resisten, antioksidan, vitamin dan mineral (Yusrina et al., 2020). 


\section{Kadar Protein}

Berdasarkan hasil analisis proksimat, kandungan protein pada perlakuan NP1 (nasi beras puth : pisang kepok 60\%: 40\%) adalah sebesar 2,719\%. Sebagai salah satu jenis serealia, nasi mengandung protein, Kandungan protein pada nasi beras putih subtitusi pisang kepok lebih tinggi dibandingkan kadar lemaknya. Padi (Oryza sativa) merupakan salah satu tanaman pangan yang banyak dibudidayakan. Biji beras mengandung zat gizi utama berupa karbohidrat dan juga protein yang merupakan sumber zat gizi penting bagi jutaan orang di seluruh dunia, terutama di negara-negara yang sedang berkembang. Protein merupakan komponen utama kedua setelah pati. Protein beras terdiri dari empat jenis yaitu albumin (larut dalam air), globulin (larut dalam garam) dan glutelin (larut dalam alkali) (Saleh et al., 2019). Protein merupakan komponen kandungan protein nasi dapat mempengaruhi selera dan kualitas zat gizi nasi (Priya et al., 2019).

Subtitusi pisang tidak memberikan kontribusi terhadap kandungan protein nasi beras putih. Hal ini disebabkan karena pisang mentah mengandung karbohidrat yang tinggi. Pati merupakan bentuk karbohidrat yang banyak terdapat pada pisang mentah, namun mengandung protein yang rendah (Bassey \& Ezeagu, 2021).

\section{Kadar Karbohidrat}

Hasil analisis proksimat perlakuan NP1 (nasi beras puth : pisang kepok 60\% : 40\%) menunjukkan karbohidrat merupakan komponen dengan jumlah paling tinggi yaitu $56,25 \%$. Hal ini disebabkan karena nasi dan pisang mentah merupakan sumber pangan karbohidrat. Beras merupakan salah satu jenis pangan sumber karbohidrat yang banyak dikonsumsi oleh masyarakat Indonesia (Purbowati \& Anugrah, 2020). Beras (Oryza sativa L.), khususnya beras putih yang banyak dikonsumsi oleh sebagian besar penduduk dunia, memberikan asupan kalori harian sekitar 35-59\% (Nguyen \& Khanh, 2021). Beras termasuk golongan serealia dengan kandungan gizi terbesar adalah karbohidrat berupa pati yaitu sekitar $80-85 \%$. Pati beras terdiri dari dua jenis yaitu amolisa dan amilopektin (Indah \& Putri, 2020), selain sebagai sumber energi, beras mengandung beberapa jenis vitamin seperti tiamin, riboflavin dan andniasin (Oko et al., 2012).

Pisang mentah mengandung karbohidrat dalam bentuk pati sekitar 60-80 g/100 g, jumlah ini hampir sama dengan kandungan karbohidrat pada jagung dan kentang (Menezes et al., 2015). Pisang mentah mengandung karbohidrat sekitar $70-80 \%$ yang terdiri dari pati sebagai komponen utama dan polisakarida non-pati seperti pektin, hemiselulosa dan selulosa (Phillip et al., 2021).

\section{Kadar Serat Kasar}

Berdasarkan hasil analisis proksimat, kadar serat kasar pada perlakuan NP1 (nasi beras puth : pisang kepok 60\%: 40\%) adalah sebesar 12,425\%. Serat kasar merupakan golongan karbohidrat yang tidak dapat dicerna oleh tubuh tetapi sangat bermanfaat untuk saluran pencernaan. Menurut (Hardiyanti \& Nisah, 2019) pada umumnya serat makanan merupakan polisakarida. Pada analisis proksimat terdapat perbedaan antara serat makanan (dietary fiber) dan serat kasar (crude fiber). Serat kasar merupakan bagian dari bahan pangan yang 
tidak dihidrolisis oleh bahan-bahan kimia yang digunakan dalam menentukan kadar serat kasar yaitu asam sulfat $\left(\mathrm{H}_{2} \mathrm{SO}_{4} 1,25 \%\right)$ dan natirum hidroksida ( $\left.\mathrm{NaOH} 1,25 \%\right)$. Adapun serat makanan merupakan bagian bahan pangan yang tidak dapat dihidrolisis oleh enzim-enzim pencernaan.

Serat merupakan golongan karbohidrat yang tidak dapat dicerna oleh sistem pencernaan manusia. Berdasarkan strukturnya, serat terdiri dari 2 jenis yaitu serat pangan dan serat kasar. Serat pada beras terdiri dari serat makanan seperti hemiselulosa dan serat kasar seperti lignin dan kandungan serat kasar dipengaruhi oleh varietas beras (Susiyanti et al., 2020). Pisang merupakan golongan buah yang banyak mengandung zat gizi dengan komposisi yang bervariasi sesuai tingkat kematangannya. Kandungan serat kasar pada pisang mentah lebih tinggi dibandingkan dengan pisang matang. Kandungan serat kasar pisang semakin rendah seiring semakin matangnya buah pisang. Kandungan serat kasar pada pisang mentah bermanfaat dalam mengatur proses fisiologis tertentu (Kookal \& Thimmaiah, 2018).

\section{Respon Glukosa Darah}

Respon glukosa darah dilakukan terhadap relawan yang merupakan responden berjumlah 8 orang dengan tujuan untuk menentukan nilai indeks glikemik dari perlakuan terpilih yaitu perlakuan NP1 (nasi beras putih : pisang kepok $60 \%: 40 \%$ ). Karakteristik responden dan hasil pengukuran glukosa darah puasa disajikan pada Tabel 4.

Berdasarkan karakteristik responden pada Tabel 4 dapat dilihat bahwa rata-rata umur responden adalah 20,86 tahun dan semua responden berjenis kelamin perempuan. Rata-rata hasil pengukuran IMT adalah 20,87 $\mathrm{kg} / \mathrm{m}^{2}$, nilai IMT berkategori normal.

Tabel 4. Karaktersitik responden dan hasil pengukuran glukosa darah puasa

\begin{tabular}{ccccccc}
\hline No & Responden & Usia (Tahun) & Jenis Kelamin & IMT $\left(\mathrm{kg} / \mathrm{m}^{2}\right)$ & $\mathrm{LP}(\mathrm{cm})$ & $\mathrm{GDP}(\mathrm{mg} / \mathrm{dL})$ \\
\hline 1 & KQ & 21 & Perempuan & 20,39 & 65 & 96 \\
2 & WM & 21 & Perempuan & 20,59 & 65 & 89 \\
3 & $\mathrm{MA}$ & 20 & Perempuan & 24,10 & 72 & 84 \\
4 & $\mathrm{FG}$ & 20 & Perempuan & 20,85 & 66 & 85 \\
5 & $\mathrm{AC}$ & 21 & Perempuan & 18,93 & 60 & 81 \\
6 & $\mathrm{NR}$ & 22 & Perempuan & 22,03 & 72 & 81 \\
7 & $\mathrm{DL}$ & 21 & Perempuan & 19,20 & 66 & 81 \\
8 & NH & 21 & Perempuan & 20,89 & 68 & 89 \\
& Rata-rata & 20,86 & Perempuan & 20,87 & 66,75 & 85,75
\end{tabular}

Nilai rata-rata hasil pemeriksaan glukosa darah responden setiap 30 menit selama dua jam setelah pemberian makanan standar dan makanan uji disajikan pada Tabel 5 .

Tabel 5. Nilai rata-rata kadar glukosa darah responden $(\mathrm{mg} / \mathrm{dL})$

\begin{tabular}{llccccc}
\hline \multirow{2}{*}{ No } & \multirow{3}{*}{ Makanan } & \multicolumn{5}{c}{ Waktu (menit) } \\
\cline { 3 - 7 } & & 0 & 30 & 60 & 90 & 120 \\
\hline 1 & Roti tawar & 85,75 & 136,25 & 118,86 & 109,75 & 101
\end{tabular}


\begin{tabular}{lllllll}
2 & Nasi beras putih subtitusi pisang kepok & 83,86 & 116,86 & 104,5 & 84,36 & 80,50 \\
\hline
\end{tabular}

Tabel 5 menunjukan bahwa setelah 30 menit pemberian roti tawar terjadi kenaikan glukosa darah dari $85,75 \mathrm{mg} / \mathrm{dL}$ menjadi 136,25mg/dl, dan kemudian pada menit ke 60 glukosa darah turun menjadi 118,86 mg/dL. Setelah itu terus menurun hingga menit ke 120 . Sementara pada makanan uji nasi beras putih subtistusi pisang kepok setelah 30 menit pemberian roti tawar terjadi kenaikan glukosa darah dari $83.86 \mathrm{mg} / \mathrm{dL}$ menjadi 116,86 $\mathrm{mg} / \mathrm{dl}$ dan setelah itu terus menurun hingga menit ke 120. Pada makanan uji nasi beras putih subtitusi pisang kepok kenaikan glukosa darah pada 30 menit setelah pemberian makanan lebih rendah dibandingkan pada roti tawar. Hal ini menandakan bahwa makanan acuan yaitu roti tawar cepat mengalami penguraian menjadi glukosa yang menyebabkan peningkatan kadar glukosa darah setelah 30 menit mengonsumsi makanan tersebut. Berbeda dengan makanan uji yaitu nasi beras putih subtitusi pisang kepok, perubahan menjadi glukosa lebih lambat ditandai dengan nilai glukosa darah responden yang lebih rendah setelah mengonsumsi 30 menit. Subtitusi pisang kepok menyebabkan peningkatan kadar serat sehingga menurunkan nilai indeks glikemik dan menyebabkan penguraian karbohidrat menjadi lebih lambat.

Kandungan serat dapat mempengaruhi kadar glukosa darah. Serat terlarut dapat menyebabkan penurunan respon glikemik bahan makanan, adapun kandungan serat kasar dapat mempertebal kerapatan atau ketebalan campuran makanan selama berada pada saluran pencernaan, sehingga dapat memperlambat kecepatan makanan pada saluran pencernaan serta menghambat aktivitas enzim. Hal ini menyebabkan proses pencernaan menjadi lambat dan respon glukosa darah menjadi lebih rendah (Pangerang \& Rusyanti, 2018).

Perbedaan sumber karbohidrat dapat mempengaruhi respon glukosa darah sesaat setelah dikonsumsi. Faktor utama yang dapat mempengaruhi indeks glikemik adalah tingkat penyerapan kandungan karbohidrat makanan (Chaipai et al., 2018). Konsumsi makanan dengan nilai indeks glikemik tinggi dapat meningkatkan kadar gula darah dengan cepat. Makanan berkategori indeks glikemik tinggi proses pencernaanya dan penyerapannya berlangsung cepat (Juwita et al., 2020).

\section{Indeks Glikemik}

Hasil perhitungan nilai indeks glikemik pada nasi beras putih subtitusi pisang kepok dari nilai rata-rata responden seperti yang disajikan pada Tabel 5 .

Tabel 5. Indeks glikemik roti tawar dan nasi beras putih subtitusi pisang kepok

\begin{tabular}{|c|c|c|c|}
\hline No & Sampel Makanan & $\begin{array}{c}\text { Luas Area } \\
\text { di bawah Kurva }(\mathrm{cm})\end{array}$ & $\begin{array}{c}\text { Indeks } \\
\text { Glikemik (\%) }\end{array}$ \\
\hline 1 & Roti tawar & 2399,55 & 100 \\
\hline 2 & Nasi beras putih subtitusi pisang kepok & 483 & 20,13 \\
\hline
\end{tabular}


Hasil perhitungan menunjukan bahwa indeks glikemik nasi beras puth subtitusi pisang kepok termasuk kategori nilai indeks glikemik rendah. Penggolangan jenis makanan berdasarkan nilai indeks glikemik adalah, > 70 merupakan nilai indeks glikemik tinggi, 56-69 nilai indeks glikemik sedang dan <55 nilai indeks glikemik rendah (Henry et al., 2021). Indeks glikemik merupakan indikator yang digunakan untuk mengetahui efek fisiologis karbohidrat terhadap perubahan kadar glukosa darah. Makanan yang termasuk golongan indeks glikemik rendah, mengalami perubahan glukosa secara perlahan. Faktor indeks glikemik makanan sangat diperlukan bagi penderita diabetes agar tetap memiliki kesehatan yang optimal dan tidak mengalami komplikasi (Puspaningtyas et al., 2020). Pengolahan nasi putih yang disubtitusi dengan pisang kepok menghasilkan makanan dengan nilai indeks glikemik rendah. Hal ini disebabkan karena pisang merupakan salah satu jenis makanan yang memiliki indeks glikemik rendah, sehingga kombinasi jenis makanan dapat menurunkan nilai indeks glikemiknya.

Nilai indeks glikemik bahan pangan dapat dipengaruhi oleh beberapa faktor, yaitu kadar serat, perbandingan kandungan amilosa dan amilopektin, daya cerna pati, kandungan protein dan lemak serta cara pengolahan. Setiap bahan pangan mengandung komponen yang memberikan pengaruh yang berbeda-beda sehingga mempengaruhi nilai indeks glikemik (Arif et al., 2013). Nasi memiliki rasa yang khas dan dapat dicampur dengan bahan makanan lainnya sehingga diperoleh rasa yang lebih enak disertai keseimbangan nutrisi (Rohman et al., 2014). Pisang mentah tidak dapat langsung dikonsumsi karena memiliki tekstur yang masih keras. Pisang mentah mengandung pati melalui proses pemasakan kandungan pati tersebut dapat dicerna. Pisang mentah merupakan sumber serat yang baik, serta mengandung vitamin dan mineral yang memberikan efek menguntungkan bagi kesehatan (Chuathong et al., 2021).

\section{KESIMPULAN}

Kesimpulan dari hasil penelitian adalah nasi beras puth subtitusi pisang kepok tidak berpengaruh terhadap warna dan aroma, tetapi berpengaruh nyata terhadap tekstur dan berpengaruh sangat nyata terhadap rasa nasi bera puth subtitusi pisang kepok. Perlakuan terbaik diperoleh pada formulasi nasi beras putih : pisang kepok $60 \%: 40 \%$ (NP1) dengan nilai indeks glikemik 20,13\% berkategori indeks glikemik rendah.

\section{DAFTAR PUSTAKA}

Adi, A. C., Rifqi, M. A., Merryana, A., Farapti, Haryana, N. R., \& Astina, J. 2020. Effect of Cooking Methods and Rice Variety on The Sensory Quality and Consumer Acceptance. Media Gizi Indonesia (National Nutrition Journal), 15(3): 159-166. https://doi.org/10.204736/mgi.v15i3. 159-166

AOAC (Association of official analytical chemist). 2005. Official Methods Of Analysis. Washington D. C. US.

Arif, A. Bin, Budiyanto, A., \& Hoerudin. 2013. Nilai Indeks Glikemik Produk Pangan dan Faktor-faktor yang 
Mempengaruhinya. Jurnal Litbang Pertanian, 32(3): 91-99.

Ayuningrium, D. P., Fajariyah, R. N., Novirsa, R., \& Astutik, E. 2021. Relationship Between Body Mass Index and Gender With Asthma. Jurnal Berkala EPIDEMIOLOGI, 9(2): 155-122. https://doi.org/10.20473/jbe.v9i22021.115-122

Bassey, M. A., \& Ezeagu, I. E. 2021. Nutrient quality and sensory properties of unripe banana based complementary food fortified with crab meat in Nigeria. Scientific Research Journal (SCIRJ), 9(1): 16-23. https://doi.org/10.31364/SCIRJ/v9.i01.2021.P0121836

Bawati, F. E. S., \& Linawati, Y. 2013. Efek Pemberian Jus Buah Pisang Kepok (Musa paradisiaca forma typica) Terhadap Kadar Glukosa Darah Tikus Jantan Galur Wistar yang Terbebani Glukosa. JURNAL FARMASI SAINS DAN KOMUNITAS, 10(2): 87-94.

Bestari, I. L. 2020. Characteristics of Patients With Type 2 Diabetes Mellitus at Surabaya Haji General Hospital. The Indonesian Journal of Public Health, 15(3): 286-294. https://doi.org/10.20473/ijph.vl15il.2020.286-294

Chaipai, S., Kriangsinyot, W., \& Srichamnong, W. 2018. Effects of ripening stage and cooking methods on available glucose, resistant starch and estimated glycemic index of bananas (Musa sapientum; Nam-wa variety). Malaysian Journal of Nutrition, 24(2): 269-279.

Chapagai, M. ., Wan Rosli, W. ., Wan Manan, W. ., Jalil, R. A., Karrila, T., \& Pinkaew, S. 2017. Effect of domestic cooking methods on physicochemical, nutritional and sensory properties of different varieties of brown rice from Southern. International Food Research Journal, 24(3): 1140-1147.

Chaudhari, P. R., Tamrakar, N., Singh, L., Tandon, A., \& Sharma, D. 2018. Rice nutritional and medicinal properties: A review article. Journal of Pharmacognosy and Phytochemistry, 7(2): 150-156.

Chuathong, W., Sakonnakhon, W. P. N., Lilakhon, A., Ayudhaya, N. D. N., Khaodee, W., Tima, S., Intasai, N., Chaiwongsa, R., Chiampanichayakul, S., Punturee, K., \& Cressey, R. 2021. Beneficial Effects of Macaroni Made with Resistant Starch Type 4 from Unripe Banana and Turmeric Extract on Blood Clinical Chemistry and Gut Microbiota of Healthy Rats. Journal of Food and Nutrition Research, 9(7): 329-341. https://doi.org/10.12691/jfnr-9-7-2

Dilrukshi, P. G. ., Munasinghe, H., Silva, A. B. G., \& De Silva, P. G. S. 2019. Identification of Synthetic Food Colours in Selected Confectioneries and Beverages in Jaffna District, Sri Lanka P. Journal of Food Quality, 4(10), 1-8. https://doi.org/10.1155/2019/7453169

Diyah, N. W., Ambarwatu, A., Warsito, G. M., Niken, G., Heriwiyanti, E. T., Windysari, R., Prismawan, D., Hartasari, R., \& Purwanto. 2016. Evaluasi Kandungan Glukosa Dan Indeks Glikemik Beberapa Sumber Karbohidrat Dalam Upaya Penggalian Pangan Ber-Indeks Glikemik Rendah. Jurnal Farmasi Dan IImu Kefarmasian Indonesia, 3(2): 67-73.

Fairulnizal, M. M. ., Norhayati, M. ., Zaiton, A., Norliza, A. ., Rusidah, S., Aswir, A. ., Suraiami, M., Mohd Naeem, M. ., Jo-Lyn, A., Mohd Azerulazree, J., Vimala, B., \& Mohd Zainuldin, T. 2015. Nutrient content in selected commercial rice in Malaysia: An update of Malaysian food compotition database. International Food Research Journal, 22(2): 768-776.

Falcomer, A. L., Riquette, R. F. R., Lima, B. R. de, Ginani, V. C., \& Zandonadi, R. P. 2019. Health Benefits of 
Green Banana Consumption: A Systematic Review. Nutriens, 11(6):1-22 https://doi.org/10.3390/nu11061222

Garcia, U. G., Vicente, A. B., Jebari, S., Sebal, A. L., Siddiqi, H., Uribe, K. B., Ostolaza, H., \& Martin, C. 2020. Pathophysiology of Type 2 Diabetes Mellitus. International Journal of Molecular Sciences, 21(17): 6275. https://doi.org/10.3390/ijms21176275

Giyatmi, \& Anggraini, D. D. 2017. Pengaruh Jenis Nasi Terhadap Nilai Gizi dan Mutu Kimiawi Nasi Dalam Kemasan Selama Penyimpanan Sebagai Alternatif Pangan Darurat. KONVERSI, 6(1): 31-42.

Hardiyanti, \& Nisah, K. 2019. Analisis Kadar Serat pada Bakso Bekatul dengan Metode Gravimetri. Anima, 1(3): 103-107.

Henry, C. J., Quek, R. Y. C., Kaur, B., Shyam, S., \& Singh, H. K. G. 2021. A glycaemic index compendium of nonwestern foods. Nutrition and Diabetes, 11(2):1-36. https://doi.org/doi.org/10.1038/s41387-020-00145-w Nutrition

Hita, I. P. A. D., Kushartanti, B. M. W., \& Pranata, D. 2021. Hubungan Lingkar Perut dan Tekanan Darah Terhadap Status Gizi Wanita Member Senam Zumba dimasa Pandemi Covid-19. Jurnal Pendidikan Kesehatan Rekreasi, 7(1): 18-29. https://doi.org/10.5281/zenodo.4420421

Indah, S., \& Putri, S. I. 2020. Saving Cost Manejemen Rumah Tangga Dalam Penghematan Daya Listrik: Pada Perbedaan Tiga Cara Mengolah Beras Puth yang Bermanfaat Bagi Kesehatan. Jurnal IImu Manajemen, 6(1): 27-35. https://doi.org/10.31328/jim.v6i1.1307

Julfan, Harun, N., \& Rahmayuni. 2016. Pemanfaatan Kulit Pisang Kepok (Musa paradisiaca Linn) dalam Pembuatan Dodol. JOM Faperta, 3(2): 1-12.

Juwita, E., Susilowati, Mauliku, N. E., \& Nugrahaeni, D. K. 2020. Faktor yang Berhubungan dengan Kadar Gula Darah pada Penderita Diabetes Melitus Tipe 2 di Prolanis Puskesmas Kecamatan Cimahi Tengah. Journal of Nutrition College, 9(2): 87-93.

Khan, M. A. B., Hashim, M. J., King, J. K., Govender, R. D., Mustafa, H., \& Kaabi, J. Al. 2020. Epidemiology of Type 2 Diabetes - Global Burden of Disease and Forecasted Trends. Journal of Epidemiology and Global Health, 10(1): 107-111. https://doi.org/10.2991/jegh.k.191028.001

Kookal, S. K., \& Thimmaiah, A. 2018. Nutritional Composition of Staple Food Bananas of Three Cultivars in India. American Journal of Plant Sciences, 9(12): 2480-2493. https://doi.org/doi.org/10.4236/ajps.2018.912179

Lin, X., Xu, Y., Pan, X., Xu, J., Ding, Y., Sun, X., Song, X., Ren, Y., \& Shan, P.-F. 2020. open Global, regional, and national burden and trend of diabetes in 195 countries and territories: an analysis from 1990 to 2025. Scientific Reports, 10, 14790. https://doi.org/10.1038/s41598-020-71908-9

Menezes, E. W., Tadini, C. C., Tribess, T. B., Zuleta, A., Binaghi, J., Pak, N., Vera, G., Dan, M. C. T., Bertolini, A. C., Cordenunsi, B. R., \& Lakolo, F. M. 2015. Chemical Composition and Nutritional Value of Unripe Banana Flour (Musa acuminata, var. Nanicão). Plant Foods Human Nutritio, 66(3): 231-237. https://doi.org/10.1007/s11130-011-0238-0

Momongan, N. R., Kereh, P. S., \& Sriwartini, S. 2019. Indeks Glikemik Bahan Makanan Dengan Kadar Glukosa 
Darah Pada Penderita Diabetes Mellitus Tipe 2 Di Puskesmas Ranotana Weru. GIZIDO, 11(1): 36-41. https://doi.org/10.47718/gizi.v11i01.753

Muchtar, F., Panga, L., \& Hastian. 2020. Pengaruh Penyimpanan pada Suhu Rendah Terhadap Kandungan Protein dan Sifat Organoleptik Tahu. Jurnal Sains Dan Teknologi Pangan, 5(5): 3256-3264.

Nabil, B., Ouaabou, R., Ouhammou, M., Essaadouni, L., \& Mahrouz, M. 2020. Functional Properties, Antioxidant Activity, and Organoleptic Quality of Novel Biscuit Produced by Moroccan Cladode Flour "Opuntia ficusindica." Journal of Food Quality, 1-12. https://doi.org/10.1155/2020/3542398

Negara, J. ., Sio, A. ., Rifkhan, Arifin, M., Oktaviana, A. ., Wihansah, R. R. S., \& Yusuf, M. 2016. Aspek Mikrobiologis serta Sensori (Rasa, Warna, Tekstur, Aroma) pada Dua Bentuk Penyajian Keju yang Berbeda. Jurnal Ilmu Produksi Dan Teknologi Hasil Peternakan, 04(2): 286-290.

Nguyen, T. L., \& Khanh, S. T. 2021. Evaluation of the Obesity Prevention, Blood Glucose, and Blood Lipid Control of Vietnamese Rice Varieties in High-Fat Diet- Induced Obese Mice. International Journal of Food Science, 1-9. https://doi.org/doi.org/10.1155/2021/4880603

Ningrum, D. R., Nisa, F. Z., \& Pangasti, R. 2013. Indeks Glikemik dan Beban Glikemik Sponge Cake Sukun Sebagai Jajanan Berbasis Karbohidrat pada Subyek Bukan Penyandang Diabetes Mellitus. Prosiding Seminar Nasional Gizi: Food Habit and Degenerative Diseases. http://hdl.handle.net/11617/2879

Nurhayati, \& Rahmanto, D. E. 2016. Banana and Plantain as Medical food. Proceeding ICMHS, 87-91.

Oko, A. ., Ubi, B. ., Efisue, A. ., \& Dambaba, N. 2012. Comparative Analysis of the Chemical Nutrient Composition of Selected Local and Newly Introduced Rice Varieties Grown in Ebonyi State of Nigeria. International Journal of Agriculture and Forestry, 2(2): 16-23. https://doi.org/10.5923/j.jjaf.20120202.04

Pangerang, F., \& Rusyanti, N. 2018. Karakteristik dan Mutu Beras Lokal Kabupaten Bulungan Kalimantan Utara. Canrea Journal, 1(2): 107-117. https://doi.org/10.20956/canrea.v1i2.96

Pangribowo, S. 2020. Tetap Produktif, Cegah dan Atasi Diabetes Melitus. https://pusdatin.kemkes.go.id/article/view/20111800001/diabetes-melitus.html [15 November 2021].

Phillip, K. M., McGinty, R. C., Couture, G., Pehrsson, P. R., McKillop, K., \& Fukagawa, N. K. 2021. Dietary fiber, starch, and sugars in bananas at different stages of ripeness in the retail market. Plos One, 16(7): 1-21. https://doi.org/doi.org/10.1371/journal.pone.0253366

Priya T. S, R., Nelson, A. R. L. E., Ravichandran, K., \& Antony, U. 2019. Nutritional and functional properties of coloured rice varieties of South India: a review. Journal of Ethnic Foods, 6(11): 1-11. https://doi.org/10.1186/s42779-019-0017-3

Purbowati, \& Anugrah, R. M. 2020. Pengaruh Suhu dan Lama Penyimpanan terhadap Kadar Glukosa pada Nasi Putih. Nutri-Sains: Jurnal Gizi, Pangan Dan Aplikasinya, 4(1): 15-24. https://doi.org/10.21580/ns.2020.4.1.4565

Puspaningtyas, D. E., Sari, P. M., Kusuma, N. H., \& Helsius SB, D. 2020. Indeks glikemik cookies growol: studi pengembangan produk makanan selingan bagi penyandang diabetes mellitus. Jurnal Gizi Klinik Indonesia, 17(1): 34-42. https://doi.org/10.22146/ijcn.54576 
Riandani, M. 2013. Nasi Jagung Instan Berprotein Sebagai Makanan Pokok Alternatif untuk Penderita Diabetes Melitus. Food Science and Culinary Education Journal, 2(1): 10-16.

Rohman, Helmiyati, S., Hapsari, M., \& Setyaningrum, D. L. 2014. Rice in health and nutrition. International Food Research Journal, 21(1): 13-24.

Saleh, A. S. ., Wang, P., Wang, N., Yang, L., \& Xiao, Z. 2019. Brown Rice Versus White Rice: Nutritional Quality, Potential Health Benefits, Development of Food Products, and PreservationTechnologies. Comprehensive Reviews in Food Science and Food Safety, 18(4): 1070-1096. https://doi.org/10.1111/1541-4337.12449

Sari, A. R., Martono, Y., \& Rondonowu, F. S. 2020. Identifikasi Kualitas Beras Putih (Oryza sativa L.) Berdasarkan Kandungan Amilosa dan Amilopektin di Pasar Tradisional dan "Selepan" Kota Salatiga. Titian IImu: Jurnal IImiah Multi Sciences, 12(1): 24-30. https://doi.org/10.30599/jti.v12i1.599

Setyowati, I., \& Kurniawati, S. 2015. Preferensi masyarakat terhadap karakter nasi varietas unggul baru padi: Kasus di Kecamatan Cibadak, Kabupaten Lebak, Banten. PROS SEM NAS MASY BIODIV INDON, 1(4): 889-893. https://doi.org/10.13057/psnmbi/m010441

Sundari, D., Almasyhuri, \& Lamid, A. 2015. Pengaruh Proses Pemasakan Terhadap Komposisi Zat Gizi Pangan Sumber Protein. Media Litbangkes, 25(4): 235-242.

Sunita, R. 2021. Variasi Waktu Pemeriksaan Glukosa Darah Puasa pada Penderita Diabetes Melitus. Journal of Nursing and Public Helath, 9(1): 78-81.

Susiyanti, Rusmana, Maryani, Y., Sjaifuddin, Krisdanto, \& Syabana, M. A. 2020. The Physicochemical Properties of Several Indonesian Rice Varieties. BIOTROPIA, 27(1): 41-50. https://doi.org/10.11598/btb.2020.27.1.1030

Syamsiah, M., \& Masliah, M. 2019. Identifikasi Kadar Amilosa Beras Pandan Wangi dari Tujuh Kecamatan di Kabupaten Cianjur. Agroscience, 9(2): 130-136.

Toi, P. L., Anothaisintawee, T., Chaikledkaew, U., Briones, J. R., Reutrakul, S., \& Thakkinstian, A. 2020. Preventive Role of Diet Interventions and Dietary Factors in Type 2 Diabetes Mellitus: An Umbrella Review. Nutrients, 12(9): 2722. https://doi.org/10.3390/nu12092722

Van Dam, R. M. 2020. A Global Perspective on White Rice Consumption and Risk of Type 2 Diabetes. Diabetes Care, 43(11): 2625-2627. https://doi.org/doi.org/10.2337/dci20-0042

Wahyuni, P. T., \& Syauqy, A. 2015. Pengaruh Pemberian Pisang Kepok (Musa paradisiaca forma typical) Terhadap Kadar Glukosa Darah Puasa Pada Tikus Sprague Dawley Pra Sindrom Metabolik. Al of Nutrition College, 4(2): 547-556.

Yusrina, F., Puspitasari, R., Dewanti W, T., \& Wulan, S. N. 2020. Perbaikan Respon Glisemik dan Profil Lipid Setelah Mengkonsumsi Tepung Pisang Mentah Termodifikasi. Indonesian Journal of Human Nutrition, 7(2): 92-107.http://dx.doi.org/10.21776/ub.ijhn.2020.007.02.2

Zaddana, C., Almasyhuri, Nurmala, S., \& Oktaviyani, T. 2021. Snack Bar Berbahan Dasar Ubi Ungu dan Kacang Merah sebagai Alternatif Selingan untuk Penderita Diabetes Mellitus. Amerta Nutrition, 5(3): 260-275. https://doi.org/DOI:10.20473/amnt.v5i3.2021. 260-275 